\title{
Pemilihan Varietas Tebu Sesuai Lahan Menggunakan Metode Fuzzy Inferensi System Mamdani
}

\author{
Daniel Alfa Puryono \\ STIMIK AKI PATI \\ JL. Kamandowo No 13 Pati \\ E-mail : danielsempurna@gmail.com
}

\begin{abstract}
In line with the government's program to increase the yield and quality in the field of agriculture one of them is able to self-sufficiency. Thus the increase in agriculture cane ranging from seed selection in accordance with the land until the processing of sugar cane into sugar ready for sale with its main partners sugarcane farmers is a must. Indeed there are many varieties of seed cane but there are also many varieties of sugarcane that do not reach the targets with a maximum sugar production because it does not conform with the land at the time of planting, so that farmers suffered losses as well as sugar mills also can not result in the production of sugar in accordance with the target. Selection of sugarcane varieties in accordance with the conditions of land and soil types is very important to improve farm productivity and farm land. Many ways to define the appropriate criteria to obtain varieties with high yield and with a low tonnage in order to produce more sugar at once can reduce transportation costs and cut transport costs. Because sugarcane varieties largely determines the success of the production of sugar in the plant because basically sugar made in the garden, one way of selecting appropriate seeds whith fuzzy logic. This study aims to determine the varieties of sugar cane in accordance with the land by using a model of Mamdani Fuzzy Inference System or often also known as min-max method. Analysis of the system to get the output is done in several steps, namely the establishment of fuzzy sets, Establishment of rules, rules of composition determination, discernment (defuzzification). While the selection of appropriate varieties of sugar cane land based species and varieties of sugarcane, soil, drainage, climate such as rainfall and temperature, sunlight and air speed. The results of this study shows the results obtained proved to be better and more natural. Researchers made this system is expected to help cane farmers and sugar mills in making more accurate decisions to be in recommendations to farmers and overseers field. Because the report is valid and there is no duplication or manipulation of data.
\end{abstract}

Keywords : Fuzzy Inferensi Sytem Mandani; Sugarcane Varieties; Type of Land; MATLAB

\section{Pendahuluan}

Sejalan dengan program pemerintah untuk meningkatkan hasil dan kwalitas di bidang pertanian salah satunya adalah bisa swasembada gula. Maka dari itu peningkatan di bidang pertanian tebu mulai dari pemilihan bibit yang sesuai dengan lahan sampai proses pengolahan tebu menjadi gula dengan mitra utamanya petani tebu rakyat menjadi suatu keharusan. Karena bahan baku produksi gula terbesar diperoleh dari petani tebu rakyat.

Memang ada banyak varietas bibit tebu akan tetapi ada banyak juga varietas tebu yang tidak mencapai target produksi gula dengan maksimal karena tidak sesuai dengan lahan pada saat tanam, sehingga petani mengalami kerugian serta pabrik gula juga tidak bisa mengahasilkan produksi gula sesuai dengan target. Pemilihan varietas tebu yang sesuai dengan kondisi lahan, jenis tanah, suhu udara, perolehan sinar matahari dan tingkat curah hujan sangat penting untuk meningkatkan produktivitas kebun maupun lahan pertanian.

Pada umumnya petani tebu menanam varietas dengan tonase tinggi yang biasanya didapat dari sogolan atau biasa disebut tunas yang muncul saat tebu sudah tua, sogolan atau tunas memang menambah tonase tetapi mengurangi rendemen (kadar kandungan gula dalam batang tebu ). Dari beberapa permasalahan diatas untuk itu petani harus memilih varietas dengan rendemen tinggi dan dengan tonase yang rendah supaya dapat menghasilkan gula yang lebih banyak, sekaligus bisa mengurangi biaya transportasi dan biaya tebang angkut. Karena varietas tebu sangat menentukan kesuksesan produksi gula di pabrik karena pada dasarnya gula dibuat di kebun bukan di pabrik gula.

Ada banyak metode yang dapat digunakan dalam menerapkan sistem pemilihan varietas tebu yang sesuai dengan lahan diantaranya menggunakan Fuzzy Inference System Mamdani. 
Logika fuzzy dan teori himpunan fuzzy menunjukkan potensi yang besar untuk menyelesain secara efektif permasalahan ketidak pastian. Penerapan logika fuzzy dalam bidang pertanian dimulai pada awal tahun 70 -an, setelah ada publikasi sebelumnya dari Zadeh (1965). Salah satu hal yang paling penting yang dibuat oleh Zadeh adalah Fuzzy Rule-Based System (FRBS) atau disebut juga dengan Fuzzy Inference System (FIS). Fuzzy inference adalah proses merumuskan pemetaan dari input yang diberikan ke output dengan menggunakan logika fuzzy (Puryono 2014). Pemetaan kemudian menjadi dasar dari mana suatu keputusan diambil.

Beberapa penelitian terdahulu yang sudah terbukti berhasil mengunakan metode FIS Mamdani dengan tingkat akurasi kebenaraanya diatas $76 \%$ di antaranya tentang sistem keputusan pemilihan tanaman genetika terhadap resiko lingkungan (Camastra et al. 2015). Pada penelitian sebelumnya juga untuk penentuan kualitas manggis dan strategi peningkatan kualitas manggis. Dimana kedua tahapan tersebut dilakukan dengan menggunakan teknik Sistem Pakar Fuzzy (Fuzzy Expert System) (Purnomo 2010). Ada juga penelitian tentang perencanaan produksi roti berdasarkan permintaan (Apriyanti \& Aksad 2012). Serta bisa untuk mengevaluasi nilai pencapaian hasil belajar siswa dengan menggunakan logika fuzzy (Gokmen et al. 2010).

Selain itu ada juga keberhasilan penelitian dengan menggunakan Metode Fuzy Infernce System (FIS) Mamdani dengan mengunakan program MATLAB. Diantaranya pernah dilakukan untuk pemilihan suplier berdasarkan 3 kriteria, yaitu ekonomi, lingkungan dan sosial. Dimana data yang ada kemudian diolah berdasarkan ketiga kriteria tersebut dengan menggunakan program aplikasi MATLAB dan akan didapatkan rekomendasi pemilihan suplier yang terbaik (Amindoust et al. 2012). Serta masih ada juga penelitian yang mengunakan metode FIS Mamdani dengan bantuan program MATLAB untuk mengevaluasi tanah longsor dan kerentanan tanah pada skala menengah (Akgun et al. 2012).

\section{Kerangka Teori}

\subsection{FIS Mamdani dan MATLAB}

MATLAB (Matrix Laboratory) adalah sebuah program untuk analisis dan komputasi numerik, merupakan suatu bahasa pemrograman matematika lanjutan yang dibentuk dengan dasar pemikiran menggunakan sifat dan bentuk matriks (Prabowo \& Rahmadya 2012).

Keberhasilan MATLAB juga telah teruji dalam Program MamLand yang dikembangkan dan diterapkan pada kasus Sinop (Northern Turki). Menggunakan MamLand dan FIS Mamdani yang dapat menghasilkan dataset yang sangat besar dapat diproses dengan mudah (Akgun et al. 2012).

Dalam dekade terakhir ini, FIS Mamdani telah digunakan secara luas untuk memecahkan masalah yang kompleks dan juga masalah nonlinear seperti geologi rekayasa. Karakteristik yang menarik dan mungkin yang paling menarik dari beberapa model kabur jika dibandingkan dengan metode lain yang biasa digunakan dalam geosains, seperti statistik, karena FIS Mamdani mampu menggambarkan masalah tersebut secara transparan.

\subsection{Fuzzy Logic}

Fuzzy logic memberikan metodologi untuk model ketidakpastian dengan cara seperti cara berpikir manusia, penalaran dan persepsi. Dalam model klasik variabel memiliki nilai bilangan real, hubungan didefinisikan dalam hal fungsi matematika, dan output adalah nilai-nilai numerik. Model dengan logika fuzzy memiliki variabel yang mempengaruhi perilaku sistem dan hubungan antar variabel yang menggambarkan sistem tersebut. Dalam logika fuzzy, nilai-nilai variabel dinyatakan dengan istilah-istilah bahasa seperti besar, menengah, dan kecil, hubungan didefinisikan dalam hal aturan jika-maka, dan output yang subset kabur yang dapat dibuat nilai menggunakan teknik defuzzifikasi. Nilai-nilai variabel sistem yang fuzzified untuk mengekspresikan mereka dalam hal bahasa. Fuzzifikasi adalah metode untuk menentukan derajat keanggotaan dimana nilai harus himpunan fuzzy tertentu. Serta ditentukan dengan mengevaluasi fungsi keanggotaan himpunan fuzzy sedangkan untuk nilai fungsi keanggotaan adalah fungsi matematika, yang mendefinisikan derajat keanggotaan suatu elemen dalam himpunan fuzzy (Alavi 2012).

Himpunan merupakan kumpulan atau koleksi objek yang didefinisikan secara jelas dan pasti dalam sembarang urutan dan tak diperhatikan keberurutan objek-objek anggotanya. Objekobjek itu disebut anggota atau elemen himpunan. Sedangkan logika adalah suatu displin yang berhubungan dengan metode berpikir. Pada tingkat yang paling dasar, logika memberikan aturan-aturan dan teknik-teknik untuk 
menentukan apakah suatu argumen yang diberikan adalah valid atau benar.

Fuzzy diperkenalkan oleh Lotfi A. Zadeh pada tahun 1965 sebagai cara matematis untuk merepresentasikan ketidakpastian linguistik. Berdasarkan konsep logika fuzzy, faktor-faktor dan kriteria-kriteria dapat diklasifikasikan tanpa batasan yang mengikat. Logika fuzzy sangat berguna untuk menyelesaikan banyak permasalahan dalam berbagai bidang yang biasanya memuat derajat ketidakpastian (Puryono 2014).

Pada himpunan klasik (crisp), keanggotaan suatu elemen (x) dalam suatu himpunan (A), sering dinotasikan dengan hanya ada 2 nilai keanggotaan, yaitu untuk $\mathrm{x}$ menjadi anggota $\mathrm{A}$ dan untuk $x$ bukan anggota dari A. Jika $x$ adalah kumpulan obyek yang dinotasikan dengan $\mathrm{x}$, maka himpunan fuzzy dalam $\mathrm{x}$ adalah himpunan pasangan berurutan :

$$
A=\{(x, \mu A(x)) \mid x \in X\}
$$

Fungsi keanggotaan (membership function) adalah suatu kurva yang menunjukkan pemetaan titik-titik input data ke dalam nilai keanggotaannya (derajat keanggotaan) yang memiliki interval antara 0 sampai 1 . Salah satu cara yang dapat digunakan untuk mendapatkan nilai keanggotaan adalah dengan melalui pendekatan fungsi. Ada beberapa fungsi yang bisa digunakan, antara lain: representasi linear, representasi kurva segitiga, representasi kurva trapesium, representasi kurva bentuk bahu, representasi kurva-s, representasi kurva bentuk lonceng.

\subsection{Fuzzy Inference System (FIS) Mamdani}

Metode Mamdani sering juga dikenal dengan nama Metode Max-Min. Metode ini diperkenalkan oleh Ebrahim Mamdani pada tahun 1975. Untuk mendapatkan output, diperlukan 4 tahapan: (1) Pembentukan himpunan fuzzy; (2) Aplikasi fungsi implikasi (aturan); (3) Komposisi aturan; (4) Penegasan (deffuzy).

1. Pembentukan himpunan fuzzy

Pada Metode Mamdani, baik variabel input maupun variabel output dibagi menjadi satu atau lebih himpunan fuzzy.

2. Aplikasi fungsi implikasi

Pada Metode Mamdani, fungsi implikasi yang digunakan adalah Min.

3. Komposisi Aturan

Tidak seperti penalaran monoton, apabila sistem terdiri-dari beberapa aturan, maka inferensi diperoleh dari kumpulan dan korelasi antar aturan. Ada 3 metode yang digunakan dalam melakukan inferensi sistem fuzzy yaitu: max, additive dan probabilistik OR (probor). (Puryono 2014).

a. Metode Max (Maximum)

Dimana solusi himpunan fuzzy diperoleh dengan cara mengambil nilai maksimum aturan, kemudian menggunakannya untuk memodifikasi daerah fuzzy dan mengaplikasikannya ke output dengan menggunakan operator OR (union). Jika semua proposisi telah dievaluasi, maka output akan berisi suatu himpunan fuzzy yang merefleksikan konstribusi dari tiaptiap proposisi. Secara umum dapat dituliskan :

$\mu_{\text {sf }}[\mathrm{xi}]<--\max \left(\mu_{\mathrm{sf}}[\mathrm{xi}], \mu_{\mathrm{kf}}[\mathrm{xi}]\right)$

dengan:

$\mu \mathrm{sf}[\mathrm{xi}]=$ nilai keanggotaan solusi fuzzy sampai aturan ke-i;

$\mu \mathrm{kf}[\mathrm{xi}]=$ nilai keanggotaan konsekuen fuzzy aturan ke-i;

Apabila digunakan fungsi implikasi MIN, maka metode komposisi ini sering disebut dengan nama MAX-MIN atau MIN-MAX atau MAMDANI.

b. Metode Additive (Sum)

Pada metode ini, solusi himpunan fuzzy diperoleh dengan cara melakukan bounded-sum terhadap semua output daerah fuzzy. Secara umum dapat dituliskan sebagai berikut :

$\mu \mathrm{sf}[\mathrm{xi}]<--\min (1, \mu \mathrm{sf}[\mathrm{xi}]+\mu \mathrm{kf}[\mathrm{xi}])$

dengan:

$\mu \mathrm{sf}[\mathrm{xi}]=$ nilai keanggotaan solusi fuzzy sampai aturan ke-i;

$\mu \mathrm{kf}[\mathrm{xi}]=$ nilai keanggotaan konsekuen fuzzy aturan ke-i;

c. Metode Probabilistik OR (Probor)

Pada metode ini, solusi himpunan fuzzy diperoleh dengan cara melakukan product terhadap semua output daerah fuzzy. Secara umum dapat dituliskan sebagai berikut :

$\mu \mathrm{sf}[\mathrm{xi}]<--(\mu \mathrm{sf}[\mathrm{xi}]+\mu \mathrm{kf}[\mathrm{xi}]$ -

$\left(\mu \mathrm{sf}[\mathrm{xi}]^{*} \mu \mathrm{kf}[\mathrm{xi}]\right)$

dengan:

$\mu \mathrm{sf}[\mathrm{xi}]=$ nilai keanggotaan solusi fuzzy sampai aturan ke-i;

$\mu \mathrm{kf}[\mathrm{xi}]=$ nilai keanggotaan konsekuen fuzzy aturan ke-i;

4. Penegasan (defuzzy)

Input dari proses defuzzifikasi adalah suatu himpunan fuzzy yang diperoleh dari komposisi aturan-aturan fuzzy, sedangkan output yang dihasilkan merupakan suatu bilangan pada domain himpunan fuzzy 
tersebut. Sehingga jika diberikan suatu himpunan fuzzy dalam range tertentu, maka harus dapat diambil suatu nilai crsip tertentu sebagai outputnya.

Ada beberapa metode defuzzifikasi pada komposisi aturan MAMDANI, antara lain:

a. Metode Centroid (Composite Moment)

Pada metode ini, solusi crisp diperoleh dengan cara mengambil titik pusat $\left(\mathrm{Z}^{*}\right)$ daerah fuzzy. Secara umum dirumuskan:

$$
z^{*}=\frac{\int_{Z} z \mu(z) d z}{\int_{Z} \mu(z)} \text { atau } z^{*}=\frac{\sum_{j-1}^{n} z_{j} \mu\left(z_{j}\right)}{\sum_{j-1}^{n} \mu\left(z_{j}\right)}
$$

\section{b. Metode Bisektor}

Pada metode ini, solusi crisp diperoleh dengan cara mengambil nilai pada domain fuzzy yang memiliki nilai keanggotaan separo dari jumlah total nilai keanggotaan pada daerah fuzzy. Secara umum dituliskan:

$$
\int_{\Re_{1}}^{p} \mu(z) d z=\int_{p}^{\Re_{n}} \mu(z) d z
$$

c. Metode Mean of Maximum (MOM)

Pada metode ini, solusi crisp diperoleh dengan cara mengambil nilai rata-rata domain yang memiliki nilai keanggotaan maksimum.

d. Metode Largest of Maximum (LOM)

Pada metode ini, solusi crisp diperoleh dengan cara mengambil nilai terbesar dari domain yang memiliki nilai keanggotaan maksimum.

e. Metode Smallest of Maximum (SOM)

Pada metode ini, solusi crisp diperoleh dengan cara mengambil nilai terkecil dari domain yang memiliki nilai keanggotaan maksimum.

\subsection{Pemilihan Varietas Tebu}

Tanaman tebu tergolong tanaman perdu dengan nama latin Saccharum officinarum. Di daerah Jawa Barat disebut Tiwu, di daerah Jawa Tengah dan Jawa Timur disebut Tebu atau Rosan. Sistematika tanaman tebu adalah:

Divisi : Spermatophyta, Subdivisi : Angiospermae, Kelas : Monocotyledone, Ordo : Graminales, Famili : Graminae, Genus : Saccharum, Species : Saccarum officinarum.

Tanaman tebu tumbuh didaerah tropis dan sub tropis sampai batas garis isoterm $200 \mathrm{C}$ yaitu antara 190 LU- 350 LS. Kondisi tanah yang baik bagi tanaman tebu adalah yang tidak terlalu kering dan tidak terlalu basah, selain itu akar tanaman tebu sangat sensitif terhadap kekurangan udara didalam tanah sehingga pengairan dan drainase harus sangat diperhatikan. Drainase yang baik dengan kedalaman sekitar 1 meter dapat memberikan peluang akar tanaman menyerap air dan unsur hara pada lapisan yang lebih dalam sehingga pertumbuhan tanaman pada musim kemarau tidak terganggu. Selain itu juga dapat manyalurkan kelebihan air dimusim penghujan sehingga tidak terjadi genangan air yang dapat menghambat pertumbuhan tanaman karena berkurangnya oksigen dalam tanah.

Dilihat dari jenis tanah, tanaman tebu dapat tumbuh baik pada berbagai jenis tanah seperti tanah alluvial, grumosol, latosol dan regusol dengan ketinggian antara $0-1400$ meter diatas permukaan laut. Akan tetapi lahan yang paling sesuai adalah kurang dari 500 meter diatas permukaan laut. Sedangkan pada ketinggian > 1200 meter diatas permukaan laut pertumbuhan tanaman relative lambat. Kemiringan lahan sebaiknya kurang dari $8 \%$, meskipun pada kemiringan sampai $10 \%$ dapat juga digunakan untuk areal yang dilokalisir. Kondisi lahan terbaik untuk tebu adalah berlereng panjang, rata dan melandai sampai antara $2 \%$ sampai $5 \%$ (Indrawanto 2010).

Pemilihan varietas harus memperhatikan sifat-sifat varietas unggul yaitu, memliki potensi produksi gula yang tinggi melalui bobot tebu dan rendemen yang tinggi, memiliki produktivitas yang stabil dan mantap, memiliki ketahanan yang tinggi untuk kekerasan dan kekeringan, serta tahan terhadap hama dan penyakit.

Mengingat masa panen tebu dilakukan pada saat yang relatif serempak, akan tetapi ditanam pada waktu yang lebih panjang karena bergiliran, maka perlu diatur komposisi penanaman varietas dengan umur masak yang berbeda, yaitu masak awal, masak tengah dan masak lambat.

1. Varietas Genjah (masak awal), mencapai masak optimal 8 sampai dengan 10 bulan.

2. Varietas Sedang (masak tengahan), mencapai masak optimal pada umur lebih dari 10 sampai dengan 12 bulan.

Varietas Dalam (masak lambat), mencapai masak optimal pada umur lebih dari 12 bulan.

\section{Metodologi}

Fuzzy Inferensi System adalah sistem aturan berdasarkan logika fuzzy dimana digunakan sebagai alat untuk mewakili pengetahuan yang berbeda tentang suatu masalah, serta untuk memodelkan interaksi dan hubungan yang ada 
antara variabel tersebut. Fuzzy Inferensi System Mamdani yang diusulkan supaya bisa untuk membantu para petani tebu dalam memilih bibit tebu atau varietas tebu yang sesuai dengan lahan yang dimiliki agar hasilnya bisa lebih maksimal.

Sistem yang diusulkan terdiri dari 4 input, 1 output, dan 192 aturan untuk menghasilkan keputusan apakah varietas tebu tersebut cocok untuk jenis lahan pertanian tersebut.

Untuk pengujian sistem dilakukan dengan menginput data jenis dan varietas tebu, jenis lahan, drainase, curah hujan serta iklim seperti suhu, sinar matahari dan kecepatan angin.

Beberapa jenis nama varietas tebu yang di tanam petani di kabupaten pati seperti : BL, BZ 148, MIXED, PS 60, PS 132, PS 756, PS 851, PS 862, PS 864, PS 881, PS 951, PS JT 941, ROC14, PS JK, SIL-04, GP 95-316, PSCO 902, PSBM 901, VMC 76-16. Sedangkan dibawah ini adalah data golongan varietas tebu dari berbagai jenis tebu menurut masa panennya dan data kondisi lahan serta tingkat kemiringan lahan.

Tabel 1. Data Golongan Varietas Tebu

\begin{tabular}{cll}
\hline Varietas & Jenis Golongan & Umur \\
\hline Genjah & Masak Awal/Optimal & 8-10 Bulan \\
Sedang & Masak Tenggah & 10-12 Bulan \\
Dalam & Masak Lambat & 12-14 Bulan \\
\hline
\end{tabular}

Tabel 2. Kondisi Lahan

\begin{tabular}{cc}
\hline Jenis & Tingkat kemiringan \\
Ringan & $5 \%$ \\
Sedang & $8 \%$ \\
Berat & $10 \%$ \\
Sangat Berat & $30 \%$ \\
\hline
\end{tabular}

Selain itu ada beberapa hal yang mempengarui tumbuh kembangnya tanaman tebu di antaranya yaitu :

1. Suhu $15{ }^{\circ} \mathrm{C}$ sangat baik, suhu antara $24{ }^{\circ} \mathrm{C}$ $34{ }^{\circ} \mathrm{C}$ baik, suhu di atas $34{ }^{\circ} \mathrm{C}$ dan di bawah $10{ }^{\circ} \mathrm{C}$ tergolong tidak baik dan tidak optimal.

2. Curah hujan 1201-1300 mm/tahun sangat baik, 1300-1400 mm/tahun baik, 1100-1200 sedang, dibawah 100 dan diatas $1300 \mathrm{~mm} /$ tahun tergangu.

3. Terkena Angin dibawah atau sama dengan 10 $\mathrm{KM} / \mathrm{jam}$ baik dan jiika lebih dari $10 \mathrm{KM} / \mathrm{jam}$ tidak baik.

4. Baik bila terkena sinar matahari antara 11-14 jam per hari.

5. Tersedia dreinase dan pengairan yang baik. Sedangkan langkah-langkah penelitian sebagai berikut :
1. Pengumpulan Data

Meliputi data jenis dan varietas tebu, jenis lahan, drainase, curah hujan serta iklim seperti suhu, sinar matahari dan kecepatan angin.

2. Identifikasi Data

Identifikasi data dilakukan untuk menentukan variabel dan semesta pembicaraan yang diperlukan dalam melakukan perhitungan dan analisis masalah.

3. Pengolahan Data

Pada tahap ini dilakukan dengan menggunakan bantuan sofware Matlab 2012. serta menggunakan fasilitas yang disediakan pada toolbox fuzzy dan melakukan langkahlangkah sebagai berikut:

Pembentukan himpunan fuzzy, pembentukan aturan-aturan, penentuan komposisi aturan, penegasan (defuzzy) dan pengujian. Sebelum melakukan langkah-langkah di atas terlebih dahulu dilakukan peramalan. Hal ini dilakukan untuk meramalkan jenis dan varietas tebu yang paling sesuai dengan lahan.

4. Penarikan Kesimpulan

Berikut adalah daigram alir untuk penarikan kesimpulan

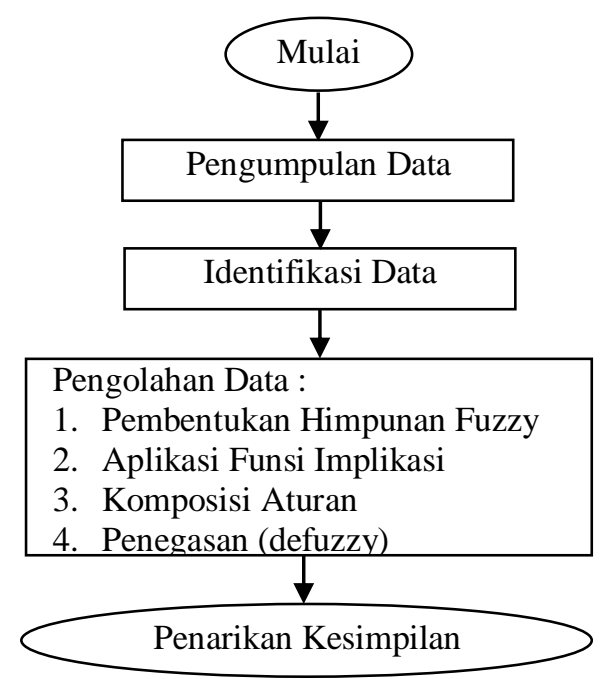

Gambar 1. Diagram Alir Penelitian

\section{Hasil dan Pembahasan}

\subsection{Hasil Penelitian}

Penelitian ini menghasilkan sebuah solusi pemilihan varietas tebu yang sesuai lahan menggunakan Fuzzy Inference System Mamdani dengan nilai kebenaran mencapai $95 \%$. Jadi metode Mamdani paling sesuai dengan naluri manusia, bekerja berdasarkan kaidah linguistik dan memiliki algoritma fuzzy yang menyediakan aproksimasi untuk dimasuki analisa matematik. 


\subsection{Kerangka Pemodelan Sistem}

Berikut adalah dasar pengetahuan yang menggambarkan perilaku sistem yang diwakili oleh fungsi keanggotaan variabel linguistik berdasarkan pada sistem pendukung keputusan.

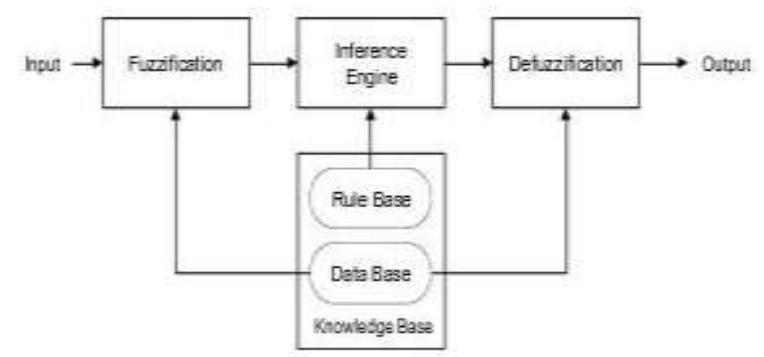

Gambar 2. Diagram Blok pada FIS

Jika di imlementasikan serta dimasukkan data-data dan variabel-veriabel yang sudah ditentukan pada program MATLAB, Maka rancangan sistemnya akan seperti pada gambar 3 dibawah ini :

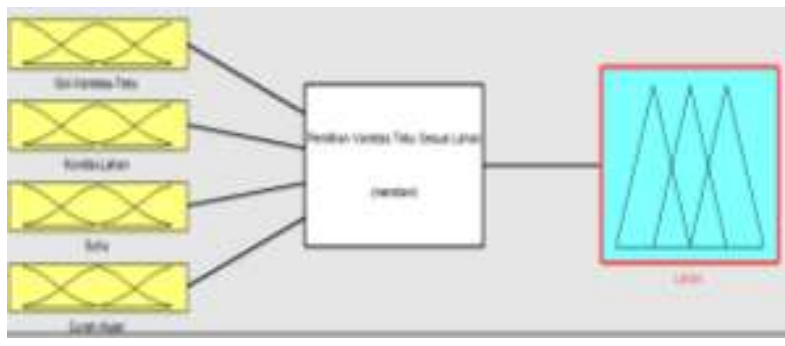

Gambar 3.Diagram FIS Pemilihan Varietas Tebu

\subsection{Masukan}

Dalam fuzzy inference system ini ada 4 buah input variabel yang merupakan masukan data golongan varietas tevu, kondisi lahan, suhu dan curah hujan.

a. Golongan Varietas Tebu

Yaitu golongan dari berbagai jenis tebu yang di tanam petani dan pabrik gula. Nilai domain dari variabel golongan varietas tebu adalah sebagai berikut :

1) Genjah : : $(8-10)$ bulan

2) Sedang : $(10-12)$ bulan

3) Dalam : (12 - 14) bulan

Fungsi keanggotaan dari variabel golongan varietas tebu dijelaskan dalam gambar 4 berikut :

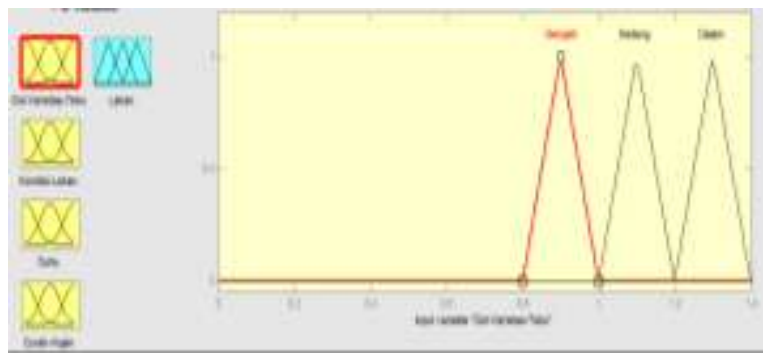

Gambar 4. Fungsi Variabel Golongan Varietas Tebu b. Kondisi Lahan

Yaitu area lahan perkebunan tebu yang di pengaruhi oleh beberapa faktor seperti tingkat kemiringan, tekanan dan arah angin, perolehan sinar matahari dan sistem dreinasenya. Sedangkan nilai domain dari variabel kondisi lahan adalah sebagai berikut :
1) Ringan
$:(0 \%-5 \%)$
2) Sedang
$:(6 \%-9 \%)$
3) Berat
$:(10 \%-29 \%)$
4) Sangat berat : $(30 \%-50 \%)$

Fungsi keanggotaan dari variabel kondisi lahan dijelaskan dalam gambar berikut :

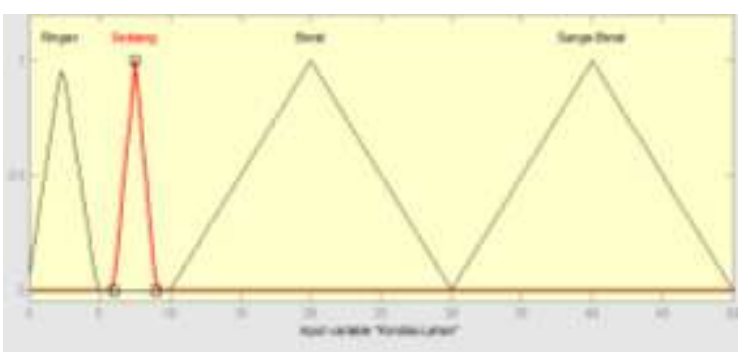

Gambar 5. Fungsi Variabel Kondisi Lahan

c. Suhu

Adalah merupakan hasil dari keseluruhan radiasi yang merupakan kombinasi emisi panjang gelombang dan aliran panas dalam tanah. Suhu tanah juga disebut intensitas panas dalam tanah dengan satuan derajat Celcius. Nilai domain dari variabel suhu adalah sebagai berikut :
1) Sangat baik
: $\left(14{ }^{\circ} \mathrm{C}-16^{\circ} \mathrm{C}\right)$
2) Sedang
: $\left(24^{\circ} \mathrm{C}-34^{\circ} \mathrm{C}\right)$
3) Tidak baik
: $\left(34^{\circ} \mathrm{C}-45^{\circ} \mathrm{C}\right)$
4) Tidak optimal
: $\left(0{ }^{\circ} \mathrm{C}-10{ }^{\circ} \mathrm{C}\right)$

Fungsi keanggotaan dari variabel suhu dijelaskan dalam gambar berikut :

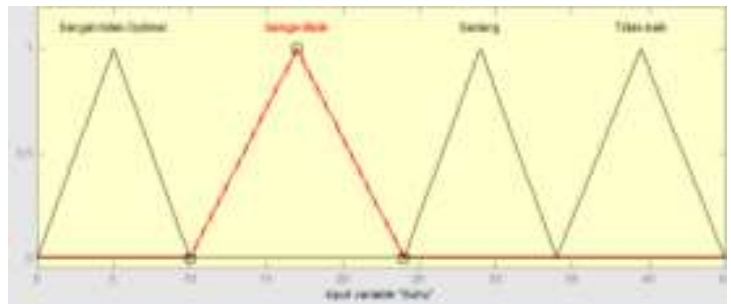

Gambar 6. Fungsi Variabel Suhu

d. Curah Hujan

Adalahjumlah air yang jatuh di permukaan tanah datar selama periode tertentu yang diukur dengan satuan tinggi $(\mathrm{mm})$. Nilai domain dari variabel curah hujan adalah sebagai berikut :
1) Sangat baik : 1201-1300 mm/tahun
2) Baik
: $1300-1400 \mathrm{~mm} /$ tahun
3) Sedang
: 1100-1200 mm/tahun 


\section{4) Tergangu : $<=100$ dan $=>$ $1300 \mathrm{~mm} /$ tahun}

Fungsi keanggotaan dari variabel curah hujan dijelaskan dalam gambar berikut :

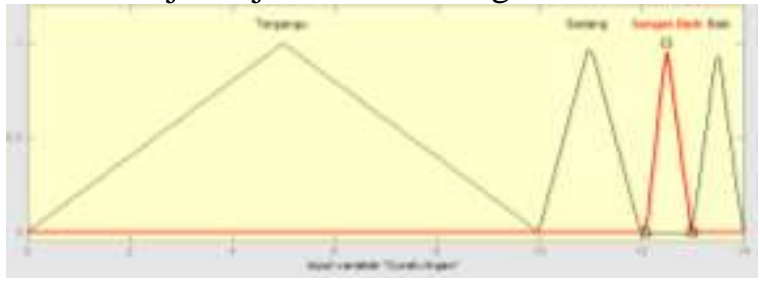

Gambar 7. Fungsi Variabel Curah Hujan

\subsection{Aturan (Rule Base)}

Dalam membuat sistem berbasis aturan ini memiliki sekumpulan fakta yang mewakili working memory. Aturan ini mencakup setiap tindakan yang harus diambil dalam ruang lingkup permasalahan yang dibutuhkan. Serta kondisi yang menentukan bahwa solusi telah ditemukan atau tidak (none exist). Hal ini berguna untuk menghindari looping yang tidak akan pernah berakhir. Dalam sistem ini ada 192 aturan yang telah ditetapkan ntuk menyeleksi pemilihan varietas tebu yang benar benar sesuai untuk jenis lahan.

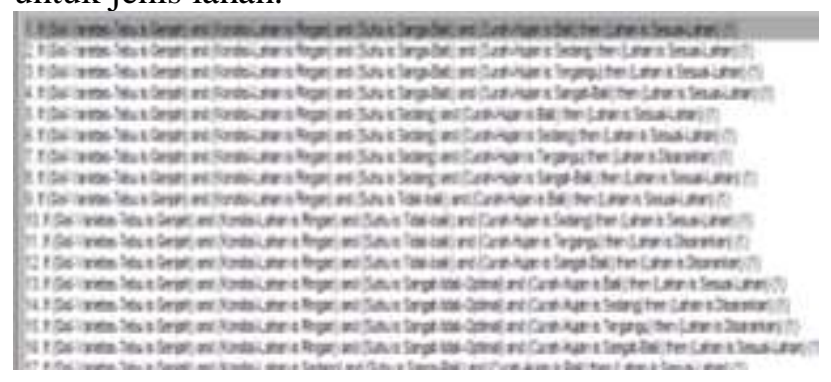

Gambar 7. Rule Base Kesesuaian Lahan

\subsection{Keluaran}

Output merupakan hasil dari proses input dan aturan (rule base) yang menghasilkan keterangan apakah varietas tebu tersebut tidak sesuai lahan, dipertimbangan, atau paling sesuai lahan. Nilai domain dari variabel golongan varietas tebu adalah sebagai berikut :
1) Tidak sesuai lahan
$:(0-0,5)$
2) Disarankan
$(0,250,75)$
3) Sesuai lahan
$(0,51,00)$

Fungsi keanggotaan dari variabel Output kesesuaian lahan dijelaskan dalam gambar berikut :

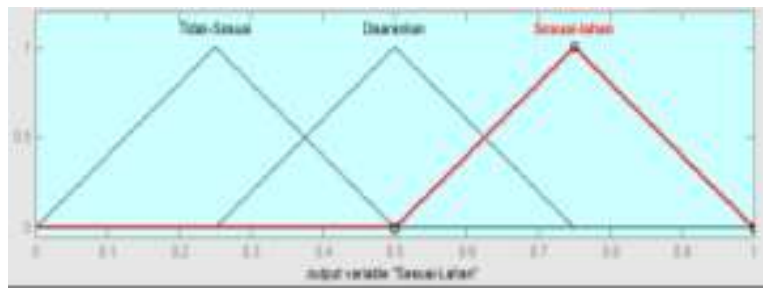

Gambar 8. Variabel Kesesuaian Lahan

\subsection{Rule Reviuw}

Rule Viewer berguna untuk melihat alur penalaran fuzzy pada sistem, meliputi pemetaan input yang diberikan pada tiap-tiap variabel. Seperti pada gambar dibawah ini

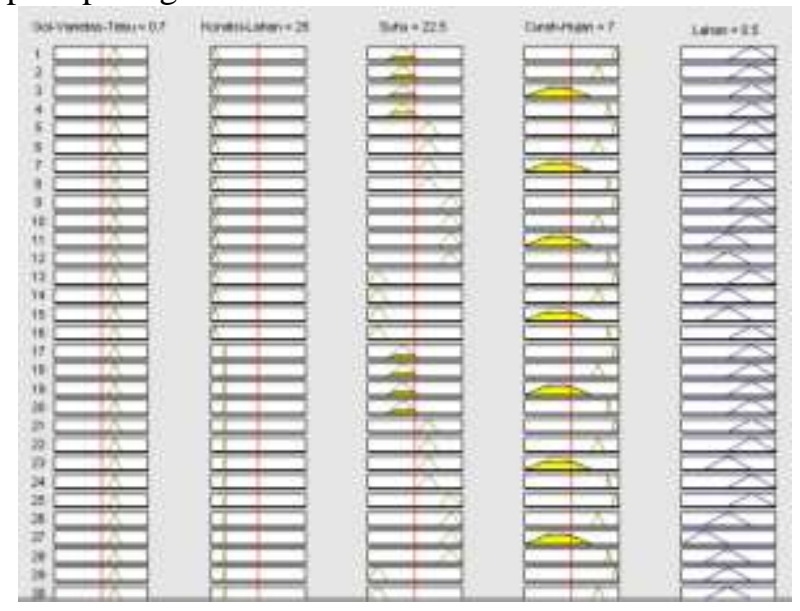

Gambar 9. Rule Viewer

\subsection{Surface Viewer}

Berguna untuk melihat gambar pemetaan antara variabel-variabel input dan variabel-variabel output dengan hasil seperti pada gambar berikut.

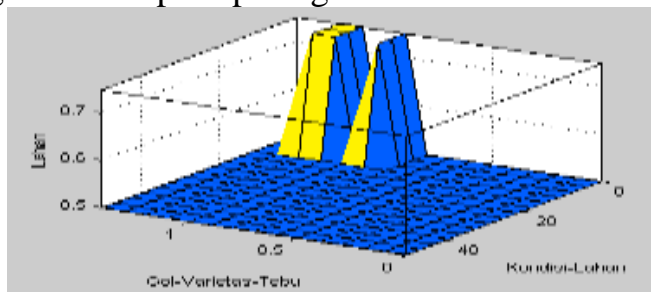

Gambar 10. Surface Viewer

\section{Kesimpulan}

Berdasarkan kegiatan selama penelitian perancangan, analisis dan implementasi pada proses yang mengunakan metode Fuzzy Inference System Mamdani dan aplikasi MATLAB untuk pemilihan jenis varietas tebu yang sesuai dengan lahan, maka dapat diambil beberapa kesimpulan seperti berikut:

Metode penelitian sistem yang digunakan adalah Fuzzy Inference System Mamdani dengan nilai kebenaran mencapai $95 \%$. Jadi metode Mamdani paling sesuai dengan naluri manusia, bekerja berdasarkan kaidah linguistik dan memiliki algoritma fuzzy yang menyediakan aproksimasi untuk dimasuki analisa matematik. Data yang diolah dalam metode FIS mamdani yaitu jenis dan varietas tebu, jenis lahan, drainase, curah hujan serta iklim seperti suhu, sinar matahari dan kecepatan angin. Data tersebut diposes melalui tahap-tahap perhitungan logika fuzzy dan memberikan keluaran dari sistem berupa rekomendasi pemilihan varietas tebu yang sesuai dengan lahan pertanian. 
Sistem dan aplikasi yang dikembangkan dapat membantu para pengambil kebijakan dalam hal ini pemilik pabrik gula serta penilik lahan pertanian supaya bisa membantu para petani tebu dengan kemungkinan hasil yang terbaik karena setiap perhitungan diperoleh dari kriteria kriteria yang dikehendaki oleh para ahli dibidangnya.

\section{Daftar Pustaka}

Akgun, A. et al., 2012. Computers \& Geosciences An easy-to-use MATLAB program ( MamLand ) for the assessment of landslide susceptibility using a Mamdani fuzzy algorithm \$. Computers and Geosciences, 38(1), pp.23-34. Available at: http://dx.doi.org/10.1016/j.cageo.2011.04.0 12.

Alavi, N., 2012. Using Mamdani fuzzy inference system to quality determination of Mozafati dates. Journal of the Saudi Society of Agricultural Sciences, 12(2), pp.137-142. Available at: http://dx.doi.org/10.1016/j.jssas.2012.10.00 1.

Amindoust, A. et al., 2012. Sustainable supplier selection: A ranking model based on fuzzy inference system. Applied Soft Computing Journal, 12(6), pp.1668-1677. Available at: http://dx.doi.org/10.1016/j.asoc.2012.01.02 3.
Apriyanti, N. \& Aksad, H., 2012. Penerapan Metode Fuzzy Mamdani dalam Perencanaan Produksi Roti.

Camastra, F. et al., 2015. A fuzzy decision system for genetically modified plant environmental risk assessment using Mamdani inference. Expert Systems with Applications, 42(3), pp.1710-1716. Available at: http://www.sciencedirect.com/science/articl e/pii/S0957417414005946.

Gokmen et al., 2010. Evaluation of Student Performance in Laboratory Applications using Fuzzy Logic. , pp.902-909.

Indrawanto, C., 2010. Budidaya dan Pasca Panen Tebu, Jakarta: ESKA Media.

Prabowo, P.W. \& Rahmadya, 2012. Penerapan Soft Computing dengan MATLAB Edisi Revi., Penerbit Rekayasa Sains Bandung.

Purnomo, D., 2010. Sistem Pakar Fuzzy Penentuan dan Penigkatan Kualitas Manggis.

Puryono, D.A., 2014. Metode Fuzzy Inferensi System Mamdani Untuk Menentukan Bantuan Modal Usaha Bagi UMKM Ramah Lingkungan. STIMIKA, 1(1). 